It is a far cry from the complexity of social and racial conditions in South Africa to the relatively simpler societies to which indirect rule has been applied. Yet the germs of South Africa's problem are there; and they will grow unless measures be taken in time. It has been said that we are waging a war in which the aim of the Allies is to establish Christian civilization as against the paganism of nationalism and the worship of the State. But as Sir Francis Younghusband has pointed out, neither Islam nor Hinduism, nor Confucianism nor other creeds can be excluded from our aims, insomuch as we welcome their assistance. Our battle is for the principles which lie at the root of Christianity, it is true, but are no less the articles of faith of all men of good will irrespective of creed-the dignity and integrity of the individual man free to develop mind and body to the limits of his capacity within free institutions. For better or for worse, white civilization has impinged upon the black. It is incumbent upon us, if we are to be really true to the principles for which we stand in the present struggle, to see to it that our rule over the less advanced peoples is a tutelage which does not overlook their claims to co-operate in a world order in the coming era of, we hope, a more rational, as well as a more humanitarian, world.

\title{
ANGLO-FRENCH CO-OPERATION IN SCHOOLS
}

$\mathrm{O}^{\mathrm{N}}$ N September 3, Lord De La Warr, who was then president of the Board of Education, visited Paris to discuss with the French Minister of Education, M. Sarraut, the contribution which the schools of the two countries can make towards Anglo-French solidarity.

The event followed a discussion in London at the end of January last on intellectual co-operation between visiting French Ministers and their opposite numbers. Committees were afterwards set up by the Education Ministries of both countries, the aim of which is to develop existing means and to devise fresh ones for increasing among the school children of each country knowledge and appreciation of the life and culture of the other country. During the visit, which was marked by a broadcast in French by M. Sarraut and Lord De La Warr, members of the two committees met to discuss each other's work. After the visit to London to which we have already referred, a special commission of experts was set up in France to recommend ways of ensuring that French children obtain a thorough knowledge of Britain and the British, the affinities and differences of the two peoples, and their common aims in eivilization. Any report which the commission has now prepared would doubtless be discussed during the Paris visit.

This move towards closer intellectual co-operation would have been desirable even had there been no war. In the present circumstances, it is inevitable and essential as a part of plans for Allied co-operation which grow more and more comprehensive. The Anglo-French declaration of war and peace policy carries with it the necessity of closer contacts between the youth and intellectual life of the two countries. Upon those who are young now will rest the responsibility of clinching victory and securing the maintenance of peace in the future. That responsibility must obviously entail closer understanding in the realm of ideas. It is in the schools, as Lord De La Warr pointed out in his broadcast, that the two peoples, so different in many ways, can learn of one another. It is in the schools that they may learn what they have both given, and are giving, to civilization and culture, what are the things for which, and against which, the present war is being waged. There was grim warning in Lord De La Warr's statement that, from the point of view of the future, the most terrible crime of the Nazi régime is the deliberate perversion of the minds and souls of their young people.

In France, where educational machinery is more centralized than in Britain, rapid innovations are possible. In English schools, nevertheless, special means have already been devised towards the ends in view. More than half a million are learning French, and the number can be increased by new effort. New programmes have been drawn up for school broadcasts and new plans for a wide circulation of films and for special lecturers to tour the schools. There are possibilities, too, of new books on French life, and of arranging exchange visits of teachers and children. These activities should make a substantial contribution to the preservation and development of the ideals for which Britain and France stand. 